\title{
THE VARIABILITY OF MEASUREMENT OF INULIN AND DIODRAST TESTS OF KIDNEY FUNCTION
}

\author{
By DEAN F. DAVIES ${ }^{1}$ AND NATHAN W. SHOCK \\ (From the National Heart Institute, National Institutes of Health, Bethesda, Maryland; and \\ the Gerontology Section, Baltimore City Hospitals, Baltimore)
}

(Submitted for publication October 25, 1949; accepted, December 28, 1949)

Estimates of glomerular filtration rate, effective renal plasma flow and tubular excretory capacity of the kidney by the methods introduced by Smith and his co-workers $(1,2)$ show variations not only between tests made on the same individual on different days but also between consecutive urine collection periods within the same test. Although it is known that the methods are adequate for demonstrating individual differences in renal function, no quantitative estimates of the accuracy of the experimental technique or the day-to-day fluctuations in renal function in the same subject have been made. Acute experiments as well as studies of the effects of an experimental regime over a period of days or weeks require for their interpretation knowledge of the magnitude of both sources of variation in kidney function.

The purpose of this study was to define the limits and to determine how much of the total variation between tests can be attributed to day-to-day physiological changes in the individual and how much can be attributed to short term changes. While part of this short term variation may result from physiological changes in the subject, it may be regarded as experimental error since it is inherent and unavoidable in the method itself.

\section{METHODS}

Experimental technique. Determinations of inulin clearance, diodrast clearance and diodrast $\mathrm{Tm}$ were carried out according to the technique previously described $(3,4)$. Minor modifications in the experimental procedure reported included the following : use of $1: 500$ nupercaine in saline in the bladder at the beginning of catheterization and again before removal of the catheter; the use of procaine hydrochloride for arterial and venous punctures; the use of the femoral artery for obtaining blood samples in the majority of tests; and maintenance of subjects in a post-absorptive state for the duration of the experiment. In addition, collection periods were shortened

1 Present address: Department of Internal Medicine, Washington University School of Medicine, Saint Louis, Mo. to eight to 11 minutes instead of the previous 12 - to 14 minute periods. Four urine collection periods were taken for the estimation of clearance values followed by four periods of the estimation of $\mathrm{Tm}$ on each test.

Subjects. Male subjects were selected according to criteria previously described $(3,4)$ from the Baltimore City Hospitals and Infirmary as well as the house staff of the Hospitals. Determinations were made on each of two days on 40 subjects ranging from 27 to 89 years of age. The two tests on the same subject were made at intervals of one week to one year.

Statistical analysis. Analysis of the variance (variance $\left.=\sigma^{2}\right)$ for each of the variables tested $\left(\mathrm{Cl}_{\mathrm{IN}}, \mathrm{Cl}_{\mathrm{D}}\right.$, and $\mathrm{Tm}_{\mathrm{D}}$ ) was carried out (5). The 40 subjects were classified in three age groups for the purpose of analysis. (Group I; $\mathrm{n}=13, \mathrm{Mn} 41.2$ years, range 27-53 years. Group II; $n=14, M n=63.7$ years, range $54-70$ years. Group III ; $n=13, M n=81.3$ years, range $71-89$ years.) The data, consisting of 320 values (four urine collection periods on each of two days for 40 subjects) provide 319 degrees of freedom which were partitioned as shown in Table I by the analysis of variance (5). In certain in-

\section{TABLE I}

Partition of total variance of measurements of renal function

\begin{tabular}{|c|c|c|c|}
\hline Effects & $\begin{array}{c}\text { Degrees } \\
\text { of } \\
\text { freedom }\end{array}$ & Effects (interactions) & $\begin{array}{l}\text { Degrees } \\
\text { of } \\
\text { freedom }\end{array}$ \\
\hline \multirow[t]{2}{*}{$\begin{array}{l}\text { Main Effects } \\
\text { Individuals, Total } \\
\text { Between age groups } \\
\text { Within age groups } \\
\text { Collection Periods, } \\
\text { Total } \\
\text { Linear regression } \\
\text { Deviations from re- } \\
\text { gression } \\
\text { Doys }\end{array}$} & \multirow[t]{2}{*}{$\begin{array}{c}(39) \\
2 \\
37 \\
(3) \\
1 \\
2 \\
1\end{array}$} & $\begin{array}{c}\text { First Order Interaction } \\
\text { Period X age groups } \\
\text { Days X age groups } \\
\text { Periods } \times \text { days } \\
\text { Periods } X \text { indiv. within } \\
\text { one age group } \\
\text { Days } X \text { indiv. within } \\
\text { one age group } \\
\text { Second Order Interaction } \\
\text { Period } X \text { day } X \text { age } \\
\text { Period } X \text { day } X \text { indiv. }\end{array}$ & $\begin{array}{r}6 \\
2 \\
3 \\
111 \\
37 \\
6 \\
111\end{array}$ \\
\hline & & Total & 319 \\
\hline
\end{tabular}

stances where values were available for only three clearance periods, the fourth clearance was calculated as the mean of the three sets of measures.

From the tables of mean squares, standard deviations of the measurements obtained under different experimental arrangements were calculated. Differences significant at the 5 and 1 per cent levels were estimated for repeated measurements on the same subject under the different experimental arrangements. 


\section{RESULTS}

The total analysis carried out according to Table I was consolidated into the smaller number of categories relevant to the present problem as shown in Table II.

Individual differences. The results of the analysis show clearly that individuals vary by a greater amount than can be explained by period-to-period or day-to-day variation, with respect to all three measurements of kidney function (Table II, line 2). Although part of the variance shown may be due to age differences of approximately 20 years, it has been shown that the contribution of age within this range is small (4).

TABLE II

Analysis of variance-summary table of mean squares

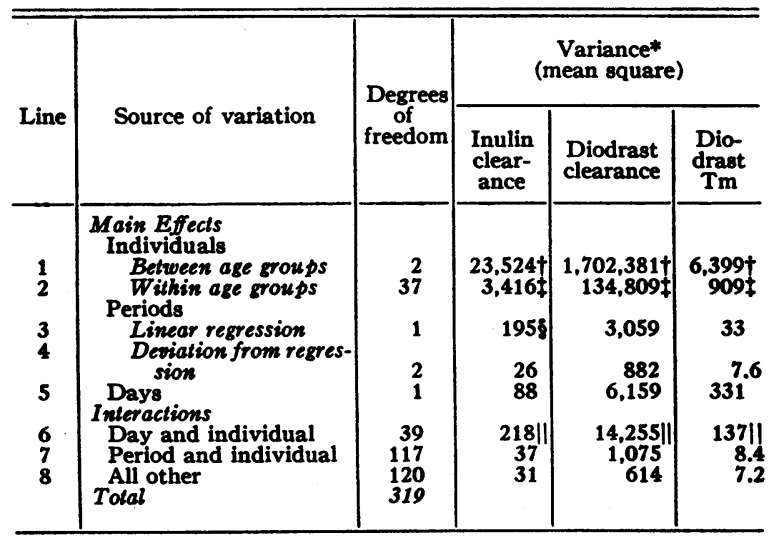

* Variance $=(\text { standard deviation })^{2}$.

† Significant at .01 level compared to variation within age groups.

$\ddagger$ Significant at .01 level compared to all interactions.

Significant at .05 level compared to period and individual variation.

II Significant at .01 level compared to period and individual variation.
Age. Significant differences between the three age categories were observed in all three functions (Table II, line 1). ${ }^{2}$

Older subjects showed less variation, both from period-to-period on the same day and from day-today, than did the younger ones. The mean values for the older subjects were significantly lower than those for the young. The percentage variation decreased slightly but systematically with age (Table III).

Period variation-Systematic. There is some evidence of a systematic decrease in measurements made in successive periods of the same test. The regression of average values of a period on the ordinal number of the period is significant at the 5 per cent level for measurements of inulin clearance and is only slightly below the 5 per cent level of significance for $\mathrm{Tm}_{\mathrm{D}}$ (Table II, line 3 ). This tendency for values to diminish with successive periods cannot be definitely established from the present experiment.

Period variation-Random (experimental error). The interaction between periods and individuals (Table II, line 7 ) is essentially a measure of how observations on the same individual vary from collection period to collection period on a single day, after the observations are corrected for individual differences, day-to-day differences, and possible systematic differences between periods on the same day. The only systematic difference approaching significance was that due to linear regression. Measurements on successive collection periods on the same individual on the same day will group themselves around the average

${ }^{2} \mathrm{~A}$ more complete assessment of age changes is reported in the following paper (4).

TABLE III

Effect of age on variability of repeated measurements

\begin{tabular}{|c|c|c|c|c|c|c|c|c|c|c|}
\hline & & & & & \multicolumn{6}{|c|}{ Standard deviations } \\
\hline \multicolumn{2}{|c|}{ Age } & \multicolumn{3}{|c|}{ Mean values } & \multicolumn{3}{|c|}{ Between periods for same day } & \multicolumn{3}{|c|}{$\begin{array}{l}\text { Between days adjusted for } \\
\text { period variation }\end{array}$} \\
\hline $\begin{array}{l}\text { Age } \\
\text { group }\end{array}$ & $\begin{array}{c}\text { Mean age } \\
\text { (years) }\end{array}$ & $\begin{array}{l}\text { Inulin* } \\
\text { clearance }\end{array}$ & $\begin{array}{l}\text { Diodrast* } \\
\text { clearance }\end{array}$ & $\underset{\text { Tm }}{\text { Diodrast }}$ & $\begin{array}{l}\text { Inulin* } \\
\text { clearance }\end{array}$ & $\begin{array}{l}\text { Diodrast* } \\
\text { clearance }\end{array}$ & $\underset{\text { Tm }}{\text { Diodrast }}$ & $\begin{array}{l}\text { Inulin* } \\
\text { clearance }\end{array}$ & $\begin{array}{l}\text { Diodrast* } \\
\text { clearance }\end{array}$ & $\underset{\text { Tm }}{\text { Diodrast } \dagger}$ \\
\hline III & $\begin{array}{l}41 \\
64 \\
81\end{array}$ & $\begin{array}{r}111.1 \\
92.4 \\
81.4\end{array}$ & $\begin{array}{l}599 \\
464 \\
344\end{array}$ & $\begin{array}{l}50.7 \\
40.7 \\
35.2\end{array}$ & $\begin{array}{l}7.8 \\
6.0 \\
3.9\end{array}$ & $\begin{array}{l}38 \\
37 \\
21\end{array}$ & $\begin{array}{l}3.0 \\
3.0 \\
2.6\end{array}$ & $\begin{array}{l}9.0 \\
5.9 \\
4.9\end{array}$ & $\begin{array}{l}80 \\
40 \\
49\end{array}$ & $\begin{array}{l}7.1 \\
6.0 \\
3.9\end{array}$ \\
\hline
\end{tabular}

* All clearance values expressed as cc./1.73 sq.m./min.

† Tm values expressed as $\mathrm{mg} . \mathrm{I} / 1.73 \mathrm{sq} . \mathrm{m} . / \mathrm{min}$. 
value with a standard deviation of $6.1 \mathrm{cc} . / 1.73$ sq.m./min. for inulin clearance $(\sqrt{37}$, Table II, line $7), 33 \mathrm{cc} . / 1.73 \mathrm{sq} . \mathrm{m} . / \mathrm{min}$. for diodrast clearance $(\sqrt{1075})$, and $2.9 \mathrm{mg}$. I/1.73 sq.m./min. for diodrast $\operatorname{Tm}(\sqrt{8.4})$.

Day-to-day variation. The variation of an individual from day to day is significantly greater than the experimental (period-to-period) variation (Table II, line 6). The day-to-day variation may be adjusted for experimental errors as shown in Table IV. If $\mathrm{n}$ measurements (periods) are

TABLE IV

Estimation of day-to-day variation, adjusted for experimental errors

\begin{tabular}{l|c|c|c}
\hline \hline \multirow{1}{*}{ Renal function } & $\begin{array}{c}\text { Observed } \\
\text { mean square } \\
\text { for day and } \\
\text { individual }\end{array}$ & $\begin{array}{c}\text { Observed } \\
\text { mean square } \\
\text { for experi- } \\
\text { mental error }\end{array}$ & $\left.\begin{array}{c}\text { Estimated Day } \\
\text { Variance* } \\
\text { (Col. 1 - Col. 2) }\end{array}\right]$ \\
\cline { 2 - 4 } & $(1)$ & $(2)$ & 4 \\
\hline $\begin{array}{l}\text { Inulin clearance } \\
\text { Diodrast clearance } \\
\text { Diodrast Tm }\end{array}$ & $\begin{array}{r}218 \\
14,255 \\
137\end{array}$ & $\begin{array}{r}1,075 \\
8\end{array}$ & $\begin{array}{r}3,295 \\
32\end{array}$ \\
\hline
\end{tabular}

* Variance $=(\text { Standard deviation })^{2}$.

made on the same subject on each of two different days, the standard error of the difference in the average values for the two days may be calculated as $\sqrt{2\left(s_{d}^{2}+\frac{s_{p}^{2}}{n}\right)}$, where $s_{d}^{2}$ is the adjusted day-to-day variance (Table IV, col. 3) and $s^{2}$ is the mean square experimental error (Table II, line 7). From this formula it is possible to compute values of the standard error of the difference between two means each based on an indefinitely large number of collection periods. This standard error depends only on the day-to-day variation of individuals and is not influenced by experimental errors. Thus for inulin clearance, the standard error of a single test on one day is $12.8 \mathrm{cc}$. $\left(\sqrt{\left.2\left(45+\frac{37}{1}\right)\right)}\right.$, but when $n$ is infinitely increased, the standard error is reduced to $9.5 \mathrm{cc}$. $(\sqrt{2(45+0)})$. For diodrast clearance, standard error is reduced from $93.5 \mathrm{cc} . / 1.73 \mathrm{sq} . \mathrm{m} . / \mathrm{min}$. for a single collection period to $81.2 \mathrm{cc}$. for an infinite number of tests. For $\mathrm{Tm}_{\mathbf{D}}$, the corresponding values are 9.0 and $8.1 \mathrm{mg}$. I/1.73 sq.m./min. respectively. Thus, because of the large individual day-to-day variation, the number of collection periods used makes only a moderate contribution to the total variance and increasing the number of periods beyond two or four does not reduce the error appreciably.

In order to judge the effect of an experimental regime on renal function, it is necessary to know how great a difference could occur in successive measurements solely because of chance errors in technique and day-to-day variations in the subject. Under the conditions of our experiments, when all age groups are combined, the probability that differences as large or larger than those shown in Table $\mathrm{V}$ could arise from these sources is small ( $P=5$ or 1 per cent). Consequently, observed differences of this magnitude or larger can be ascribed to the experimental regime. Thus, a difference as large or larger than $16.9 \mathrm{cc} .(1.96 \sqrt{2 \times 37})$ may be expected in only 5 per cent of the measurements of inulin clearance made on two successive periods on the same subject on the same day. Table V, line 1 , gives differences required for the stated levels of significance for testing differences between single periods. Differences between the means of $n$ periods are shown in line 2 . In line 3 , the differences required for significance when each value consists of the average of four periods are shown.

When tests are made on the same individual on different days, single observations (periods) of inulin clearance must differ by more than $25.1 \mathrm{cc}$. for significance at the 5 per cent level $(33.0 \mathrm{cc}$. at the 1 per cent level, Table V, line 4). Line 5 provides the formula for calculating critical levels for significance where $n$ periods are measured on each of two days. Where four periods are averaged (as in our studies) the values for inulin clearance are $20.4 \mathrm{cc} . / 1.73 \mathrm{sq} . \mathrm{m} . / \mathrm{min}$. and 26.9 cc. at the 5 per cent and 1 per cent levels respectively (Table V, line 6).

Line 7 gives the general formula for computing levels of significance for the average $n$ tests on $q$ different days. When differences between averages, each based on four periods on each of two days are measured, the differences required for the stated levels of significance are reduced as shown in Table V, line 8.

\section{DISCUSSION}

The results of this study indicate that the day-today physiological fluctuations in kidney function contribute more to the total variance of the meas- 
TABLE $V$

Order of differences in renal function measurements on the same subject required for significance under different experimental arrangements

\begin{tabular}{|c|c|c|c|c|c|c|c|}
\hline \multirow{2}{*}{$\begin{array}{c}\text { Line } \\
1\end{array}$} & \multirow{2}{*}{$\begin{array}{c}\text { Level of significance } \\
\text { Same Day } \\
\text { Difference required be- } \\
\text { tween two single collec- } \\
\text { tions of one experiment }\end{array}$} & \multicolumn{2}{|c|}{$\begin{array}{c}\text { Inulin clearance } \\
\text { cc. } / 1.73 \text { sq. } \mathrm{m} . / \mathrm{min} .\end{array}$} & \multicolumn{2}{|c|}{$\begin{array}{l}\text { Diodrast clearance } \\
\text { cc. } / 1.73 \text { sq. m. } / \text { min. }\end{array}$} & \multicolumn{2}{|c|}{$\begin{array}{l}\text { Diodrast } \mathrm{Tm} \\
\text { mg. } I / 1.73 \text { sq.m./min. }\end{array}$} \\
\hline & & $\begin{array}{c}5 \text { per cent } \\
16.9\end{array}$ & $\begin{array}{c}1 \text { per cent } \\
22.3\end{array}$ & $\begin{array}{c}5 \text { per cent } \\
91.4\end{array}$ & $\begin{array}{c}1 \text { per cent } \\
120.5\end{array}$ & $\begin{array}{c}5 \text { per cent } \\
8.0\end{array}$ & $\begin{array}{c}1 \text { per cent } \\
10.6\end{array}$ \\
\hline 2 & $\begin{array}{l}\text { Difference required be- } \\
\text { tween means of two } \\
\text { groups of } n \text { periods each }\end{array}$ & $\frac{16.9}{\sqrt{n}}$ & $\frac{22.3}{\sqrt{n}}$ & $\frac{91.4}{\sqrt{n}}$ & $\frac{120.5}{\sqrt{n}}$ & $\frac{8.0}{\sqrt{n}}$ & $\frac{10.6}{\sqrt{n}}$ \\
\hline 3 & Where $\mathbf{n}=$ four periods & 8.5 & 11.2 & 45.7 & 60.3 & 4.0 & 5.3 \\
\hline 4 & $\begin{array}{l}\text { Different Days } \\
\text { Difference required be- } \\
\text { tween two single collec- } \\
\text { tions-one on each day }\end{array}$ & 25.1 & 33.0 & 183.3 & 241.2 & 17.6 & 23.2 \\
\hline 5 & $\begin{array}{l}\text { Difference required be- } \\
\text { tween means of } n \text { peri- } \\
\text { ods on each of two days }\end{array}$ & $\sqrt{345+\frac{284}{n}}$ & $\sqrt{598+\frac{492}{n}}$ & $\sqrt{25,305+\frac{8,256}{n}}$ & $\sqrt{43,854+\frac{14,307}{n}}$ & $\sqrt{245+\frac{64}{n}}$ & $\sqrt{426+\frac{111}{n}}$ \\
\hline 6 & Where $n=$ four periods & 20.4 & 26.9 & 165.4 & 217.8 & 16.2 & 21.3 \\
\hline 7 & $\begin{array}{l}\text { Difference required be- } \\
\text { tween means of } n \text { peri- } \\
\text { ods on each of } q \text { differ- } \\
\text { ent days }\end{array}$ & $\sqrt{\frac{345}{q}+\frac{284}{q n}}$ & $\sqrt{\frac{598}{q}+\frac{284}{q n}}$ & $\sqrt{\frac{25,305}{q}+\frac{284}{q n}}$ & $\sqrt{\frac{43,854}{q}+\frac{14,307}{q n}}$ & $\sqrt{\frac{245}{q}+\frac{64}{q n}}$ & $\sqrt{\frac{426}{q}+\frac{111}{q n}}$ \\
\hline 8 & $\begin{array}{l}\text { When } \mathrm{n}=4 \text { and } \mathrm{q}=2 \text {, } \\
\text { i.e., mean of two days } \\
\text { compared with mean of } \\
\text { two other days, with } \\
\text { four periods run on each } \\
\text { day }\end{array}$ & 14.4 & 19.0 & 117.0 & 154.0 & 11.5 & 15.1 \\
\hline
\end{tabular}

urements than do experimental errors of the method. Nevertheless, daily fluctuations are small when compared with individual difference in kidney function. Since day-to-day variance is greater than period-to-period variance, it is clear that a more accurate estimate of renal function in an individual is obtained by averaging values obtained on two or more days than by increasing the number of periods run on a single day.

\section{SUM MARY}

Determination of inulin clearance, diodrast clearance, and diodrast $\mathrm{Tm}$ were made on two different days in 40 subjects between the ages of 27 and 89 years. Analysis of variance of the observations showed: $(a)$ individual differences contributed most of the variance in all measurements, (b) a significant contribution was made by age differences, and $(c)$ in all measurements day-today fluctuations were greater than those from period-to-period.

Hence, significant day-to-day variations in kidney function occur. These variations cannot be explained in terms of chance errors in technique.

A table of minimum significant differences in determinations of inulin clearance, diodrast clearance, and diodrast $\mathrm{Tm}$ made under different experimental arrangements is given.

\section{ACKNOWLEDGMENT}

The assistance of $\mathrm{Mr}$. Jerome Cornfield of the National Cancer Institute in the statistical analysis is gratefully acknowledged. The assistance of Dr. L. E. Smith in carrying out some of the tests is gratefully acknowledged. 


\section{BIBLIOGRAPHY}

1. Smith, H. W., Goldring, W., and Chasis, H., The measurement of the tubular excretory mass, effective blood flow and filtration rate in the normal human kidney. J. Clin. Invest., 1938, 17, 263.

2. Goldring, W., and Chasis, H., Hypertension and $\mathrm{Hy}-$ pertensive Disease. The Commonwealth Fund, New York, 1944.
3. Shock, N. W., Kidney function tests in aged males. Geriatrics, 1946, 1, 232.

4. Davies, D. F., and Shock, N. W., Age changes in glomerular filtration rate, effective renal plasma flow, and tubular excretory capacity in adult males. J. Clin. Invest., 1950, 29, 496.

5. Snedecor, G. W., Statistical Methods. Iowa State College Press, Ames, Iowa, 1946. 